\title{
Examining Mobile Banking Adaptation among College Students Using Technology Acceptance Model (TAM)
}

\author{
Musaed S. AlAli (Corresponding author) \\ Assistant Professor, Department of Insurance and Banking, College of Business Studies \\ The Public Authority for Applied Education and Training (PAAET), Kuwait \\ E-mail:ms.alali@paaet.edu.kw
}

\begin{abstract}
Lamyaa S. AlAli
Instructor, Department of Computer Science, College of Business Studies

The Public Authority for Applied Education and Training (PAAET), Kuwait

E-mail: 1s.alali@paaet.edu.kw
\end{abstract}

Received: April 20, 2020

Accepted: July 7, 2020

Published: August 20, 2020

doi:10.5296/ijmis.v5i1.17561

URL: https://doi.org/10.5296/ijmis.v5i1.17561

\begin{abstract}
Students are becoming more engaged in technology in general and with mobile technology in particular. Banks try to get the most of that knowledge by offering new services to attract that market segment. The aim of this study is to investigate the factors that influence the adoption of mobile banking (m-banking) services by college of business students at the Public Authority for Applied Education and Training (PAAET) in Kuwait. The theoretical framework for this study is based on Technology Acceptance Model (TAM) - TAM for mobile services is used to explore the factors that influence users' adaptation of m-banking. The model uses the number of times student uses their mobile banking application per week as the dependent variable while the usefulness of the application, the security the application provides for the user and how easy it is to use the application as independent variables. Results obtained from this research showed that the usefulness of the mobile banking application was the most important factor affecting the adaptation of the application followed by ease in using the application and the safety variable came as the least important.
\end{abstract}

Keywords: Mobile banking, PAAET, College students, Technology Acceptance Model (TAM), OLS regression 


\section{Introduction}

Expanding a bank customer base and increasing its earnings without increasing the overhead expenses is a very challenging task for any bank management executive. Mobile banking came as a result for that dilemma, Nel et al. (2012) defined mobile banking as a digital banking channel that mainly involves performing financial transactions remotely using an application downloaded onto a mobile device such as an iPad or tablet, or mobile phone. Kourouthanassis and Giaglis (2012) stated that mobile banking (m-banking) is an expanding application of mobile commerce (m-commerce) that has drawn the attention and interest of e-commerce researchers.

Although conventional branch banking still remains important in servicing customers, it is associated with high employees and services costs (Kanchan et al., 2012). For that, banks try their best to shift their banking services to digital banking in order to reduce such costs and enhance their profitability (MacDonald \& Koch, 2006). Laukkanen (2007) stated that mobile banking can offer more control to their users over their financial needs at their convenience. Mobile banking was able to increase the customer bases of banks especially among young customers who are technology oriented and customers that live in remote areas where the nearest bank branch is far from where they live. Floh and Treiblmaier (2006) showed that mobile banking can help its users in tailoring the products and services they need at their convenience since the users can access their mobile applications 24/7 and from any location. Mobile banking enables users to access account balances, pay bills, transfer funds, manage their investments and perform many other financial services. By providing such services through their mobile application, banks would be able to reduce the number of customers visiting their branches which means that banks would be able to reduce their cost of hiring more staff and opening new branches as their customer base increases. To achieve such goals, bank invest heavily on developing user friendly platforms for their mobile banking (Hoehle \& Huff, 2012). As a result of banks investments in digital banking, AlAli and AlAli (2020) found that the level of staffing in banks has seen a global decline in the past years due to the introduction of technology aided banking, such as e-banking and m-banking.

Technology Acceptance Model (TAM) was first introduced by Davis (1986), the model uses the actual usage of the application as a measure of adaptation and the effect of the perceived usefulness, the ease in using the system and the security risk associated with the use of the application. Davis (1993) found that there was a statistically significant direct relation between the application usefulness and actual system use. Lee (2009) concluded that the intention to use online banking is primarily and positively affected by perceived benefit. Ramayah et al. (2003) examined the effect of perceived ease of use and the actual number of use and found a significant direct relation between them. Similar, Luarn and Lin (2005) found that there is a positive causality between perceived ease of use and usage intention.

\section{Methodology}

The college of business studies is a part of the Public Authority for Applied Education and Training (PAAET) which is an educational institution that was formed in 1982. Now PAAET is the largest educational institution in Kuwait with a number of students exceeding 26000. 


\section{Macrothink}

International Journal of Management Innovation Systems

ISSN 1943-1384

2020, Vol. 5, No. 1

The college of business studies has a student body of around 6500 students during the academic year 2019-2020. Following Yamane (1967) model in determining the sample size, as seen in equation 1, it can be concluded that a sample size of 220 students is not suitable to conduct the study at the $95 \%$ confidence level since it requires a sample size of 377 students. When calculating the confidence level for a sample size of 220 students, it can be found at $93.37 \%$.

$$
n=\frac{N}{1+N * \mathrm{e}^{2}}
$$

Where;

$n$ is the sample size

$N$ is the population size

$e$ is the acceptable sampling error

Using equation 2 to calculate Cronbach's alpha values which came at 0.786 which exceeds the recommended level of 0.60 (Malhotra, 2010). This would provide evidence of internal-consistency reliability of the survey.

$$
\text { Cronbach's alpha }=\frac{k * \operatorname{mean}\left(r_{\mathrm{i}}\right)}{1+\operatorname{mean}\left(r_{\mathrm{i}}\right) *(k-1)}
$$

Where;

$k$ is the number of variables

$\operatorname{mean}\left(r_{i}\right)$ is the average correlation between the variables

A quantitative approach was followed in collecting data. The data is then used, using panel OLS regression, to examine the relation between the actual number student uses his/her m-banking application per week as a dependent variable and the perceived usefulness of the application, the ease in using the application, and the security of the application as independent variables as shown in equation 3.

$$
N Y=\alpha+\beta_{1} U+\beta_{2} S+\beta_{3} E+\varepsilon
$$

Where $N Y$ is the number of actual use per week, $U$ is the perceived usefulness of the application, $S$ is the safety of the application, and $E$ is the ease in using the application.

\section{Data and Empirical Results}

The results of this research are based on a questionnaire that was distributed to 256 students at the college of business studies at the Public Authority for Applied Education and Training (PAAET) in Kuwait during the first semester of the 2019/2020 academic year. Out of the 256 
questionnaires distributed, 36 were omitted due to incomplete forms. The participants consist of 114 female and 106 male students.

Table 1. Questionnaire results

\begin{tabular}{|c|c|c|}
\hline Variable & Number & Percentage \\
\hline Do you think the application useful? & \multicolumn{2}{|c|}{} \\
\hline Yes & 176 & $80 \%$ \\
No & 3 & $1.36 \%$ \\
Don't Know & 41 & $18.64 \%$ \\
Total & 220 & $100 \%$ \\
\hline Yes you think the Application Safe? & 138 & $62.73 \%$ \\
No & 10 & $4.54 \%$ \\
Don't Know & 72 & $32.73 \%$ \\
Total & 220 & $100 \%$ \\
\hline Yes & 153 & $69.55 \%$ \\
No & 12 & $5.45 \%$ \\
Don't Know & 55 & $25 \%$ \\
Total & 220 & $100 \%$ \\
\hline
\end{tabular}

Questionnaire results are presented in table 1, from the table it can be seen that $80 \%$ of the participants found their mobile banking applications to be useful while only $1.36 \%$ of them think otherwise. In terms of application security issues, $62.73 \%$ of the participants think that their mobile banking applications are secured. When it comes to how easy and user friendly their mobile banking applications are, $69.55 \%$ of the participants think that the application is easy to used and user friendly.

In determining the importance of technology acceptance model (TAM) factors, it can be seen from table 2, that the three factors can explain $53.97 \%$ of the mobile banking application adaptation among students and that the model can be labeled as a "good fit" in determining such a relation since the $F$ Sig of the model is 0 . In terms of individual factor effect, it can be seen that there is a statistically significant direct relation between the perceived usefulness of the application and the number of times used per week at the $99 \%$ confidence level. In terms of the expected safety and security of the application against hacking, it can be seen that there is a statistically significant direct relation but at the $90 \%$ confidence level. The user friendly and the ease in using the application showed a statistically significant direct relation with the number student uses his/her application at the 95\% confidence level. When using the coefficient to determine the weight of the effect of each factor, it can be concluded that the usefulness of the application is the most important factor followed by the ease in using the application and finally the security issue comes at the bottom when deciding to use mobile banking among students. 
Table 2. Panel OLS regression output

\begin{tabular}{|l|l|l|l|l|}
\hline R Square & 0.6107 & & $F$ Stat & 19.219 \\
\hline Adj R Square & 0.5397 & & $F$ Significance & 0.000 \\
\hline Observations & 220 & & & \\
\hline & Coefficients & $t$ Stat & $P$-value & \\
\hline Intercept & -0.001 & -0.003 & 0.998 & \\
\hline Useful & 1.313 & 2.792 & $0.006 * * *$ & \\
\hline Safe & 0.665 & 1.793 & $0.074 *$ & \\
\hline Easy & 0.897 & 2.198 & $0.029 * *$ & \\
\hline$*, * * * * *$ represent the confidence level at $90 \%, 95 \%$, and $99 \%$ respectively \\
\hline
\end{tabular}

\section{Conclusion}

This study was set to examine the factors influencing the use of mobile banking applications among student at the college of business studies using technology acceptance model (TAM). Using the questionnaire results of 220 students, results showed that perceptive usefulness of the application was the factor that mostly affects students usage followed by the ease in using the application and the security concern was the least influencing factor affecting the use of mobile banking applications among students.

\section{References}

AlAli, L. S., \& AlAli, M. S. (2020). Exploring Factors Influencing Mobile-Banking Usage among PAAET College of Business Studies Students. International Journal of Computer Science and Mobile Computing, 9(4), 95-104.

Davis, F. D. (1986). A technology acceptance model for empirically testing new end-user information systems: theory and results. Massachusetts: MIS. (Thesis - PhD).

Davis, F. D. (1993). User acceptance of information technology: System characteristics, user perceptions and behavioral impacts, International Journal of Man-Machine Studies, 38(3), 475-487. https://doi.org/10.1006/imms.1993.1022

Floh, A., \& Treiblmaier, H. (2006). What keeps the e-banking customer loyal? A multi group analysis of the moderating role of consumer characteristics on e-loyalty in the financial service industry. Journal of Electronic Commerce Research, 7(2), 97-110. https://doi.org/10.2139/ssrn.2585491

Hoehle, H., \& Huff, S. (2012). Advancing task-technology fit theory: a formative measurement approach to determining task-channel fit for electronic banking channels. In D. N. Hart, \& S. D. Gregor (Eds.), Information Systems Foundations: Theory Building in Information Systems (pp. 133-169). ANU E Press. https://doi.org/10.22459/ISF.10.2012.06

Kanchan, A., Banerjee, B., Wilson, D., \& Sullivan, W. (2012). Trends in retail banking channels: Improving client service and operating costs. Retrieved from https://www.capgemini.com/resource-fileaccess/resource/pdf/Trends_in_Retail_Banking_Ch 
annels__Improving_Client_Service_and_Operating_Costs.pdf

Kourouthanassis, P. E., \& Giaglis, G. M. (2012). Introduction to the special issue mobile commerce: The past, present, and future of mobile commerce research. International Journal of Electronic Commerce, 16(4), 5-18. https://doi.org/10.2753/JEC1086-4415160401

Laukkanen, T. (2007). Internet vs. mobile banking: Comparing customer value perceptions, $\begin{array}{lllll}\text { Business Process } \quad \text { Management } & \text { J8urnal, }\end{array}$ https://doi.org/10.1108/14637150710834550

Lee, M. C. (2009). Factors influencing the adoption of internet banking: An integration of TAM and TPB with perceived risk and perceived benefit. Electronic Commerce Research and Applications, 8(3), 130-141. https://doi.org/10.1016/j.elerap.2008.11.006

Luarn, P., \& Lin, H. H. (2005). Toward an understanding of the behavioral intention to use mobile banking, Computers in Human Behavior, 21(6), 873-891. https://doi.org/10.1016/j.chb.2004.03.003

MacDonald, S. S., \& Koch, T. C. (2006). Management of Banking (7th ed.). USA: Thomson Corporation.

Malhotra, N. K. (2010). Marketing research: An applied orientation. New Jersey: Pearson Prentice Hall.

Nel, J., Boshoff, C., \& Raleting, T. (2012). Exploiting the technology cluster effect to enhance the adoption of WIG mobile banking among low-income earners. Management Dynamics, 21(1), 30-44.

Ramayah, T., Jantan, M., Nasser, M. N., Koay, P. L., \& Razli, C. R. (2003). Receptiveness of internet banking by Malaysian consumers: The case of Penang, Asian Academy of Management Journal, 8(2), 1-29.

Yamane, T. (1967). Statistics: An Introductory Analysis (2nd ed.). USA, New York: Harper and Row.

\section{Copyright Disclaimer}

Copyright for this article is retained by the author(s), with first publication rights granted to the journal.

This is an open-access article distributed under the terms and conditions of the Creative Commons Attribution license (http://creativecommons.org/licenses/by/3.0/). 